\title{
A social-ecological impact assessment for public lands management: application of a conceptual and methodological framework
}

\author{
$\underline{\text { Amanda L. Bentley Brymer }}^{1}, \underline{\text { Joseph D. Holbrook }}^{2}, \underline{\text { Ryan J. Niemeyer }}^{3}, \underline{\text { Alexis A. Suazo }}^{4}, \underline{\text { J. D. Wulfhorst }}^{1,5,6}, \underline{\text { Kerri T. Vierling }}^{2}$, Beth $^{2}$
} A. Newingham ${ }^{7}$, Timothy E. Link ${ }^{4,5}$ and Janet L. Rachlow ${ }^{2}$

\begin{abstract}
According to the U.S. National Environmental Policy Act of 1969 (NEPA), federal action to manipulate habitat for species conservation requires an environmental impact statement, which should integrate natural, physical, economic, and social sciences in planning and decision making. Nonetheless, most impact assessments focus disproportionately on physical or ecological impacts rather than integrating ecological and socioeconomic components. We developed a participatory social-ecological impact assessment (SEIA) that addresses the requirements of NEPA and integrates social and ecological concepts for impact assessments. We cooperated with the Bureau of Land Management in Idaho, USA on a project designed to restore habitat for the Greater Sage-Grouse (Centrocercus urophasianus). We employed questionnaires, workshop dialogue, and participatory mapping exercises with stakeholders to identify potential environmental changes and subsequent impacts expected to result from the removal of western juniper (Juniperus occidentalis). Via questionnaires and workshop dialogue, stakeholders identified 46 environmental changes and associated positive or negative impacts to people and communities in Owyhee County, Idaho. Results of the participatory mapping exercises showed that the spatial distribution of social, economic, and ecological values throughout Owyhee County are highly associated with the two main watersheds, wilderness areas, and the historic town of Silver City. Altogether, the SEIA process revealed that perceptions of project scale varied among participants, highlighting the need for specificity about spatial and temporal scales. Overall, the SEIA generated substantial information concerning potential impacts associated with habitat treatments for Greater Sage-Grouse. The SEIA is transferable to other land management and conservation contexts because it supports holistic understanding and framing of connections between humans and ecosystems. By applying this SEIA framework, land managers and affected people have an opportunity to fulfill NEPA requirements and develop more comprehensive management plans that better reflect the linkages of social-ecological systems.
\end{abstract}

Key Words: deliberative workshops; impact assessment; National Environmental Policy Act; NEPA; PPGIS; public lands; public participatory GIS; social-ecological systems

\section{INTRODUCTION}

When federal actions aimed at species conservation in the United States are anticipated to cause significant impacts to the environment, land and resource managers are required by the National Environmental Policy Act of 1969 (NEPA; 42 U.S.C. $\S 4331$ et seq.) to assess potential impacts, develop mitigation strategies, and report their findings in an environmental impact statement (EIS). NEPA stipulates an interdisciplinary approach so that the entire environment is included in planning and decision making (Council on Environmental Quality 2007). Even so, a typical EIS tends to comprise more ecological than social impacts, and assessments that integrate ecological and social concepts to identify impacts at multiple scales are uncommon (Burdge 2002, Franks et al. 2011, Whitfield et al. 2011, Whitfield and Reed 2012).

A social impact is defined as a cognitive or physical effect experienced by humans and their communities and caused by a change in the social or ecological environment (Vanclay 2002). Traditionally, secondary sources such as census data are analyzed to identify potential social impacts (Becker 1997), but secondary data can be inappropriate when sources are outdated or lack information on specific community needs or cultural issues (Esteves et al. 2012). Consequently, a typical social impact assessment (SIA) lacks current primary data (Lockie 2001) and rarely invites stakeholders to engage actively in planning or assessment processes (Vanclay and Esteves 2011).

Effective SIA facilitates the evaluation and management of social issues associated with planned interventions (e.g., management or land-use change) and is participatory, supportive of people affected by interventions, and increases people's capacity to respond to change (Esteves et al. 2012). However, Esteves et al. (2012) identified a set of issues that persist in SIA, including inadequate public participation and analyses that do not identify spatial or temporal distributions of impacts. Research has demonstrated that dialogue-based approaches to SIA such as interactive community forums and participatory modeling can help to overcome these limitations by providing a more comprehensive and deeper understanding of values, place meanings, and perceived impacts (Becker et al. 2003, Harris et al. 2012, Whitfield and Reed 2012). Rather than predicting impacts from secondary data sources, an emerging paradigm of SIA seeks a community-based process that empowers affected people with improved understanding of a project and increased capacity to negotiate outcomes with the project managers or developers (Vanclay and Esteves 2011).

${ }^{1}$ Environmental Science Program, University of Idaho, ${ }^{2}$ Department of Fish and Wildlife Sciences, University of Idaho, ${ }^{3}$ Department of Civil and Environmental Engineering, University of Washington, ${ }^{4}$ Department of Forest, Rangeland, and Fire Sciences, University of Idaho, ${ }^{5}$ Water Resources Program, University of Idaho, ${ }^{6}$ Department of Agricultural Economics \& Rural Sociology, University of Idaho, ${ }^{7}$ Great Basin Rangelands Research Unit, USDA-Agricultural Research Service 
Reconciling the shifting SIA paradigm and the requirements for NEPA processes highlights the need for novel methodological approaches that can capture social dynamics such as political tensions among different interest groups, as well as diverse perspectives on changing ecological conditions. The design of such approaches should assist public land managers in developing socially and ecologically comprehensive management plans that aid in decision making and ultimately help to achieve conservation goals. Our research objective was to develop a social-ecological impact assessment (SEIA) that addresses the requirements of NEPA and embodies the emerging SIA paradigm calling for more participatory, dialogue-based approaches. Our conceptual framework builds on previous work (i.e., Slootweg et al. 2001, de Groot et al. 2002, 2010, Vanclay 2002) by merging ecosystem service concepts with social process concepts to represent better the role of humans and the interdependent relationships between humans and ecosystems. The methodological approach directly engages diverse stakeholders and builds on previous work (i.e., Becker et al. 2003, Gunderson and Watson 2007, Whitfield et al. 2011, Harris et al. 2012, Whitfield and Reed 2012, Lowery and Morse 2013) by deliberating project alternatives to identify stakeholders' perceptions of potential impacts, and by adding a spatial dimension with participatory mapping to include place meanings and values across the landscape.

We contribute to this field of scholarship an integrated framework of ecosystem services and social process concepts to generate more holistic understanding of social-ecological interdependencies and effects associated with habitat conservation plans. In our case, the integrated framework was used to describe how the Owyhee region of southwestern Idaho, USA functions socially and ecologically, and to categorize potential social and ecological impacts of juniper removal. This process of identifying and describing potential impacts based on evidence and perceptions of how a system functions and adapts to dynamic changes requires the convergence of three perspectives: systems thinking (Checkland 1981, Cundill et al. 2012), complexity theory (Holling 2001, Folke 2006), and social constructivism (Lincoln and Guba 1985, 2013). In other words, we asked stakeholders how social and ecological components of the Owyhee region function and interact (systems thinking); how emergent dynamics such as juniper removal, coupled with nonlinear dynamics such as climate change, affect the Owyhee region (complexity theory); and how juniper removal is perceived to potentially alter the Owyhee region in beneficial or consequential ways (social constructivism). By relying on multiple theories and perspectives, we triangulated our interpretation of the data (Patton 2015).

We contribute to this field of practice a multimethod process that extends the range of scoping, brings affected people into project discussions and deliberations, and upholds the requirements of NEPA. Our approach specifically compares and integrates findings generated by questionnaires, deliberative workshops, and participatory mapping. For each method, we ask the same set of questions and use multiple analysts to review our findings. Thus, three types of triangulation support confidence in and validation of this holistic-inductive approach: multiple theories and perspectives, mixed methods, and multiple analysts (Patton 2015).
We apply the SEIA to a high-profile conservation context in the western United States: habitat restoration for the Greater SageGrouse (Centrocercus urophasianus; hereafter Sage-Grouse). As of January 2015, the Bureau of Land Management (BLM) has been developing a draft EIS focused on improving habitat for Sage-Grouse by removing conifer trees from important habitats. Sage-Grouse is an obligate inhabitant of sagebrush ecosystems and was considered a candidate species for listing under the Endangered Species Act (USFWS 2010) because of $>50 \%$ habitat loss since the mid-1800s (Knick et al. 2003). However, in September 2015, the USFWS decided not to list Sage-Grouse as an endangered species, but rather to designate focal areas for conservation and restoration across Sage-Grouse habitat (U.S. Department of the Interior 2015). Following this decision, the BLM continues to plan for conifer tree removal with the goal of improving Sage-Grouse habitat in focal areas. The BLM's preliminary scoping with key stakeholders (an important first step in the NEPA process) revealed controversy over the proposed spatial scale of the Bruneau-Owyhee Sage-Grouse habitat (BOSH) project, as well as opposition to the removal of native conifer trees at any scale. Given the opposing views and the looming USFWS decision, a deliberative approach to the SEIA was necessary for debating opposing points of view to achieve a clear understanding of the complexity and a broader scope of perspectives than that revealed by preliminary scoping. Public lands managers must address the issues identified during scoping with scientifically appropriate mitigation strategies. Thus, this case of Sage-Grouse habitat restoration was an opportunity to document the process and outcome of a deliberative approach to an integrated impact assessment.

\section{Proposed action: Greater Sage-Grouse habitat restoration}

The proposed study region for the treatment of Sage-Grouse habitat was in Owyhee County, Idaho, USA (Fig. 1). Owyhee County comprises $76 \%$ public lands (managed mostly by the BLM), $2092 \mathrm{~km}^{2}(11 \%$ ) of which is designated wilderness (Owyhee Initiative: http://owyheeinitiative.org). Agriculture comprises $26.1 \%$ of total employment in Owyhee County, with two-thirds of that sector engaged in ranching (University of Idaho Extension, Owyhee County: agriculture, livestock and range: http://extension.uidaho.edu/owyhee/2014/07/11/agriculture-livestockand-range/). Most ranches are not economically viable with private lands alone; these operations rely on permitted grazing on BLM allotments (Bartlett et al. 2002). Although the Owyhee region is vast and rural, it is in close proximity to the greater Boise metropolitan area (Mackun and Wilson 2011), from where many people travel for hunting, fishing, rafting, bird watching, hiking, and off-highway vehicle riding.

The habitat treatment plan proposed by the BLM was termed the BOSH project; the project goal is to improve or maintain SageGrouse breeding habitat (i.e., areas surrounding leks, which are areas for courting and mating) by removing western junipers (Juniperus spp.). Conifers, including junipers and pinyon pines (Pinus spp.), are dominant trees in Great Basin woodlands that have expanded into sagebrush habitats (Tausch et al. 1981, Romme et al. 2009). Tree expansion can negatively affect SageGrouse breeding habitat (e.g., Baruch-Mordo et al. 2013), which has prompted management actions to remove conifers. 
Fig. 1. Map of Owyhee County, Idaho, USA showing the proposed project boundary and five landmarks for the Bruneau-Owyhee Sage-Grouse Habitat project. Inset: Black polygon indicates the location of Owyhee County in western USA.

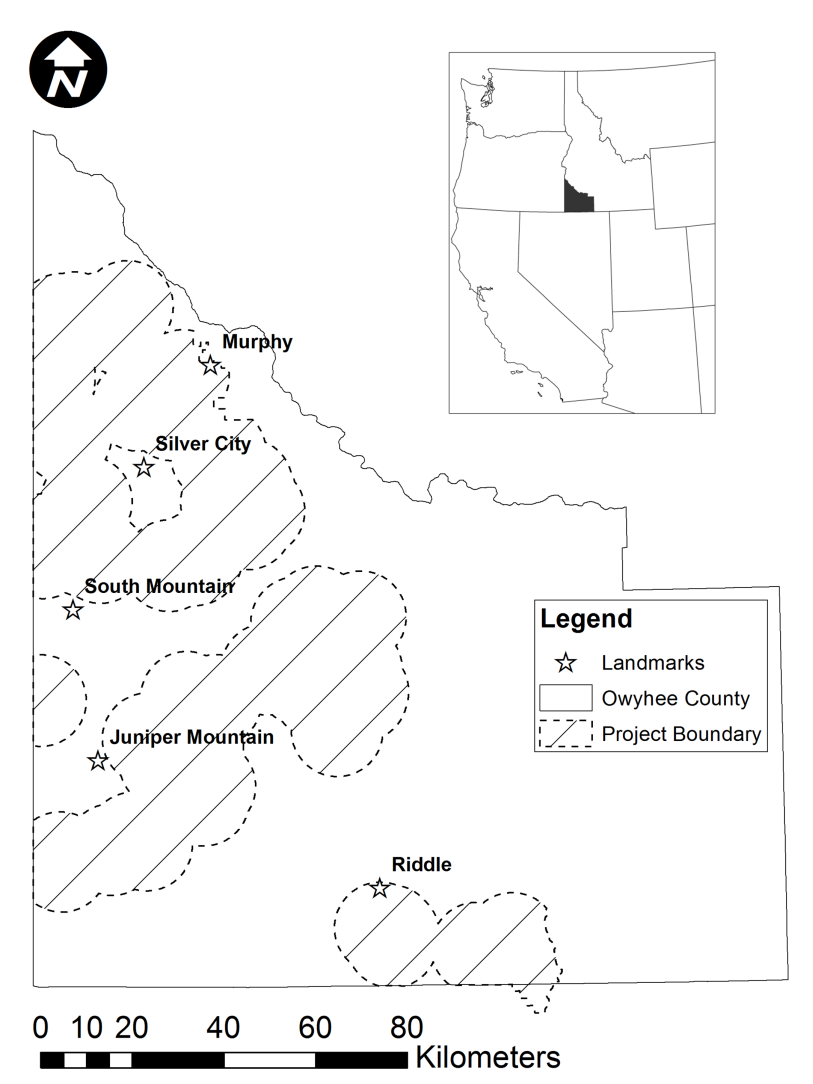

The BOSH project proposes to remove low-density western juniper stands that are within $10 \mathrm{~km}$ of 63 active Sage-Grouse leks within Owyhee County (Fig. 1). The BLM and Idaho Department of Fish and Game define active leks as those that have been visited by at least two male Sage-Grouse in at least one of the last five years. The BLM chose the $10-\mathrm{km}$ buffer because approximately $80 \%$ of hens nest within $10 \mathrm{~km}$ of their lek. The proposed project boundary covered 708,200 ha (1.75 million acres) of southwestern Idaho and included 93,078 ha $(230,000$ acres) of wilderness. Proposed treatments included cut and scatter, mastication, and jackpot burning. Cut and scatter involves cutting down trees and scattering the branches, whereas mastication uses heavy machinery that shreds the aboveground tree biomass and spreads the mulch (Cline et al. 2010). Jackpot burning involves burning the cut trees when fire risk is low (Huffman et al. 2009). In accordance with NEPA, the BLM developed treatment alternatives that included: no action (no juniper removal), full-suite treatment (cut and scatter, mastication, and jackpot burning where deemed necessary and appropriate), and cut and scatter (where deemed necessary and appropriate).

\section{SOCIAL-ECOLOGICAL IMPACT ASSESSMENT DEVELOPMENT}

Given the tightly linked social and ecological characteristics of the Owyhee region, the BOSH project presented an opportunity for investigating stakeholders' perceptions of a social-ecological system, the system's changing environmental structure and functions, and potential effects for human well-being. In our case, BLM managers were interested in using the SEIA process as a participatory approach for a more comprehensive impact assessment that fulfills the requirements of NEPA. Managers were also interested in using the SEIA as an additional scoping opportunity from which they might use participant input to guide further development of juniper removal alternatives, thus potentially gaining stakeholder buy-in for the BOSH project. We next explain the theoretical foundations and justification for our conceptual and analytical framework and methodological approach. Our specific methods as implemented in the BOSH project are described subsequently.

\section{Conceptual framework}

The foundation of our integration relies on a convergence of systems thinking, complexity theory, and social constructivism, i.e., how and why a system functions as it does; how emergent and nonlinear dynamics of complex adaptive systems can be understood; and what is perceived as real, and what the consequences are, respectively (Patton 2015:99). To construct a framework robust enough to address social-ecological dynamics, complexity, perceptions, and perceived consequences, we merged previously developed conceptual frameworks that emphasize the connection between humans and ecosystems. First, we applied concepts from de Groot et al.'s $(2002,2010)$ ecosystem services framework that provides a standardized typology for describing and classifying ecosystem functions, goods, and services: provisioning, processing and regulating, supporting, and cultural. Second, we used Vanclay's (2002) conceptualization of social processes (i.e., social system functions and services) to integrate economics, governance, and empowerment concepts with ecosystem services concepts. Economic processes relate to "the way in which people make a living and economic activity in the society," institutional and legal processes relate to "the efficiency and effectiveness of institutional structures, including government and nongovernment organizations," and empowerment processes relate to "increasing influence in decision making processes" (Vanclay 2002:193). The result of this integration is a more comprehensive framework for assessing potential socialecological changes and impacts in complex systems by including social processes as functions from which humans can derive benefits (or costs) alongside and interdependent with ecosystem services.

We adapted a function evaluation flow diagram from Slootweg et al. (2001) to serve as a guide for the identification of cause and effect pathways and for the description of potential effects on people and their communities. For example, removal of juniper trees from a landscape exemplifies an intervention that causes social-ecological change (Fig. 2). An ecological change might be a reduction in juniper. This change is filtered through an ecosystem (e.g., sagebrush) and results in an ecological effect such as improved habitat for sagebrush-obligate species. This ecological effect could then result in a positive effect for a person who appreciates improved habitat for sagebrush obligates (Fig. 2A) or in additional pathways or effects (Fig. 2B,C). 
Fig. 2. Flow diagram of the social-ecological impact assessment framework (modified from Slootweg et al. 2001). The diagram begins with an intervention (i.e., juniper removal), that leads to social or ecological change through three pathways. (A) Example of the effects of reduction in juniper abundance. (B) Juniper removal influences social change when the project is perceived to be implemented poorly, thus degrading an agency's reputation and causing a negative $(-)$ human impact in terms of public distrust of the management agency. (C) Juniper removal influences social change by providing an opportunity for public agency collaborations with private landowners, resulting in additional local-level juniper removal. This ecological change is perceived to improve grazing lands. Thus, for those who appreciate improved ranching opportunities, the human impact via this last pathway is positive (+). All arrows represent pathways to human impacts.



\section{Methodological approach}

The SEIA approach merges a deliberative workshop setting and participatory mapping activities to understand better the differing perspectives among people who live and work in the Owyhee region and to identify spatial dimensions of their values. Public participation GIS (PPGIS) is a method used to represent public knowledge, place meanings, or values spatially by including members of the public in the mapping process (Talen 2000, Brown 2004). We merged participatory, qualitative approaches to SIA (Becker et al. 2003, Harris et al. 2012) and PPGIS methods (Gunderson and Watson 2007, Lowery and Morse 2013) because there is a need and legal mandate to involve the public in planning processes (Brown and Weber 2011, Brown and Donovan 2013), and because human-ecosystem interactions and planning are inherently geospatial. Moreover, the broader justification for a deliberative approach to SEIA relates to the growing lack of consensus over how to manage shared natural resources (Parkins and Mitchell 2005) and how to represent multiple stakeholder perspectives and values (Whitfield et al. 2011). Deliberative approaches and spaces provide opportunities to debate opposing points of view; improve understanding of a situation and its complexity; expose a range of public values; and enable empathy, open-mindedness, and learning (Daniels and Walker 1996,
Parkins and Mitchell 2005, Cundill and Rodela 2012). These methods are combined too infrequently to understand potential impacts in the context of NEPA and U.S. public lands.

We designed two workshops to foster discussion about three topics: (1) the juniper removal alternatives drafted by the BLM; (2) general social, economic, and ecological values; and (3) any benefits people receive from their social-ecological system (i.e., the Owyhee region). For the first workshop, we structured questionnaires and dialogue directly around the integrated conceptual framework and the function evaluation flow diagram. For the second workshop, we asked participants to indicate areas across Owyhee County and within the BOSH project area that are socially, economically, or ecologically valuable and fundamental to their relationships to the social-ecological system.

\section{METHODS}

Prior to our agreement with the BLM, a working group comprising managers from the BLM and Idaho Department of Fish and Game, restoration conservationists from governmental and nongovernmental organizations, and representatives from the Owyhee County Sage-Grouse Local Working Group had already been formed by the project lead (hereafter Group 1). To broaden the range of perspectives for the SEIA, we purposively sampled 27 stakeholder groups whose members are concerned about the Owyhee region to create an additional workshop group (hereafter Group 2). Thus, the sampling frame included: local, state, and federal resource managers; Idaho-based nonprofit environmental conservation groups; the Shoshone-Paiute tribes; and participants in a long-term collaborative effort in the Owyhee region (i.e., the Owyhee Initiative) that served as a clearinghouse of additional resource-based organizations interested and involved in the Owyhee region. Using contact information provided on the organizations' websites, we identified key informants (e.g., President) and initiated a three-step recruitment protocol: invitation by email, reminder by email, and reminder by telephone call. We also conducted snowball sampling at each step in the recruitment protocol by asking each invitee to extend our invitation and to reply to us with contact information for other people or organizations interested in participating in the SEIA. This process resulted in Group 2. Group 1 and Group 2 separately participated in a two-workshop series. Each workshop spanned an average of $5 \mathrm{~h}$. We followed ethical guidelines for working with human subjects, and the University of Idaho Institutional Review Board approved our project.

\section{Deliberative workshops}

The first workshop began with an overview presentation of the BOSH project followed by four rounds of questionnaires and deliberation. Using the function evaluation framework as a guide (Slootweg et al. 2001), participants were asked: (1) to describe the potential cause-effect pathways from each juniper removal alternative to a range of possible ecological or social changes (or no change), and (2) to deliberate the proposed alternatives and their potential positive and negative effects (or no effect).

All four questionnaires included the same seven questions related to ecosystem services and social processes (Table 1). The first questionnaire and subsequent deliberation assessed participants' baseline perceptions of the current structure and functional capabilities of the Owyhee region in terms of ecosystem services 
and social processes. The next three rounds of questionnairedeliberation revealed participants' perceptions of future structure and function of the Owyhee region under the three BOSH project alternatives (i.e., no action, full-suite treatment, and cut and scatter). For the current state and future conditions under each alternative, participants rated items from 0 ("as bad as it can be") to 10 ("as good as it can be"). The last question related to the level of acceptability for each alternative in wilderness areas, which was different than the other questions because there was no baseline condition and the scale was from 0 ("extremely unacceptable") to 5 ("extremely acceptable"). Thus, we analyzed the wilderness question separately. Data were graphed using $\mathrm{R}$ software (R Core Team 2014).

Table 1. Questions used to evaluate participants' opinions about ecosystem service and social change processes with implementation of the Bruneau-Owyhee Sage-Grouse Habitat project in Owyhee County, Idaho, USA. Questionnaire 1 determined the baseline (i.e., "current ability") and questionnaires 2-4 determined potential future states under the three proposed alternatives (i.e., "future ability"). An additional question about the acceptability of implementing each alternative within designated wilderness was added to the end of questionnaires $2-4$.

\begin{tabular}{cl}
$\begin{array}{c}\text { Social-ecological } \\
\text { system function } \\
\text { Category }\end{array}$ & Question \\
\hline $\begin{array}{c}\text { Ecosystem services } \\
\text { Provisioning }\end{array}$ & $\begin{array}{l}\text { The current/future ability of Owyhee to } \\
\text { produce useful resources for the people is/will } \\
\text { be... } \\
\text { The current/future ability of Owyhee to } \\
\text { maintain or restore its balance through } \\
\text { physical, biological, and chemical processes } \\
\text { and interactions is/will be... } \\
\text { The current/future availability of physical } \\
\text { space that is suitable for human activities in } \\
\text { Owyhee is/will be... } \\
\text { The current/future ability of Owyhee to } \\
\text { provide opportunities for spiritual enrichment, } \\
\text { aesthetic enjoyment, contemplation, } \\
\text { meditation and recreation is/will be... }\end{array}$
\end{tabular}

Social processes

Economic

The current/future economic activity in Owyhee, including the ways people make a living, is/will be.

Institutional The current/future efficiency and effectiveness and legal of the management or supply of natural resources in Owyhee upon which stakeholders depend is/will be...

Empowerment The current/future ability of stakeholders to contribute to decision making about Owyhee that affects their lives is/will be..

Workshop dialogue was recorded and transcribed for analysis in NVivo 10 (QSR International 2012). First, the integrated socialecological conceptual framework was used to categorize participant responses into statements about particular ecosystem services and social processes. Second, an inductive approach was used to review the transcriptions and allow descriptions of potential impacts to emerge from participants' deliberations (Lincoln and Guba 1985, Patton 2015). For a potential socialecological effect to be included in the analysis, it was required to meet the following criteria:

1. Is a potential social-ecological effect explicitly described, along with the direction of its effect on people and their wellbeing (i.e., positive, negative, or no change)? If yes, the impact was included.

2. If the effect on people and their well-being is not explicitly described (i.e., positive, negative, or no change), is there a value statement (e.g., improved, better, worse, degraded) from which the effect can be clearly interpreted? If yes, the potential impact and perceived effect were included.

3. Is the participant role-playing (e.g., "Other people probably see this alternative leading to...")? If yes, the impact was not included.

\section{Public participation GIS workshop}

We implemented a qualitative approach to PPGIS (e.g., Brown and Pullar 2012, Lowery and Morse 2013). We presented participants with laminated $61 \times 91 \mathrm{~cm}$ aerial photographs (U.S. Department of Agriculture Farm Services Agency, National Agriculture Imagery Program imagery: http://www.fsa.usda.gov/ programs-and-services/aerial-photography/imagery-programs/naipimagery/) at a scale between 1:400,000 and 1:500,000. We asked each individual to draw polygons around areas across Owyhee County that they perceived as valuable for social, economic, and ecological reasons. Next, we presented a separate set of maps that displayed the BOSH project boundary and asked participants to identify areas where they did not want the project executed and to explain why. We then took photographs of each map to create a county value map by digitizing polygons within ArcGIS 10.1 (ESRI 2012). Each polygon had attributes indicating the group and participant number and whether it was based on social, economic, or ecological justification. We analyzed overlapping polygons in ArcGIS (Honeycutt 2013) across a $30 \mathrm{~m}^{2}$ grid overlaid on Owyhee County and the BOSH boundary.

\section{RESULTS}

The sample comprised 24 participants in total: 20 questionnaires were completed; 4 questionnaires were not completed and were thus not included in the analysis. Nineteen people participated in the deliberative workshops, and ten people participated in the PPGIS workshops: of those participants, eight attended both deliberative and PPGIS workshops. Participants represented diverse occupations and user groups as self-described, including four nongovernment conservationists, four wildlife biologists, three livestock ranchers and land owners, two government conservationists, two supervisors, two natural resource managers, one restoration coordinator, one range management specialist, one archaeologist, one cartography technician, one retired fire fighter, one self-employed individual, and one individual who did not self-identify an occupation. Group 1 included nongovernment conservationists, wildlife biologists, government conservationists, supervisors, natural resource managers, restoration coordinators, an archaeologist, and a nonidentified occupation. Group 2 included nongovernment conservationists, range management specialists, a cartography technician, a retired fire fighter, and a self-employed person. 
Fig. 3. Participant responses to seven questions concerning the current state of Owyhee County (i.e., baseline) and the Bruneau-Owyhee Sage-Grouse Habitat project alternatives: no action, full suite of actions, and cut and scatter. Results are displayed scored as baseline-normalized by subtracting the participant baseline score from his or her alternative score. Responses about alternatives were normalized to baseline scores (e.g., participant 1 baseline score is 7 , full suite score is 8 , and the baseline-normalized score is 1 ).

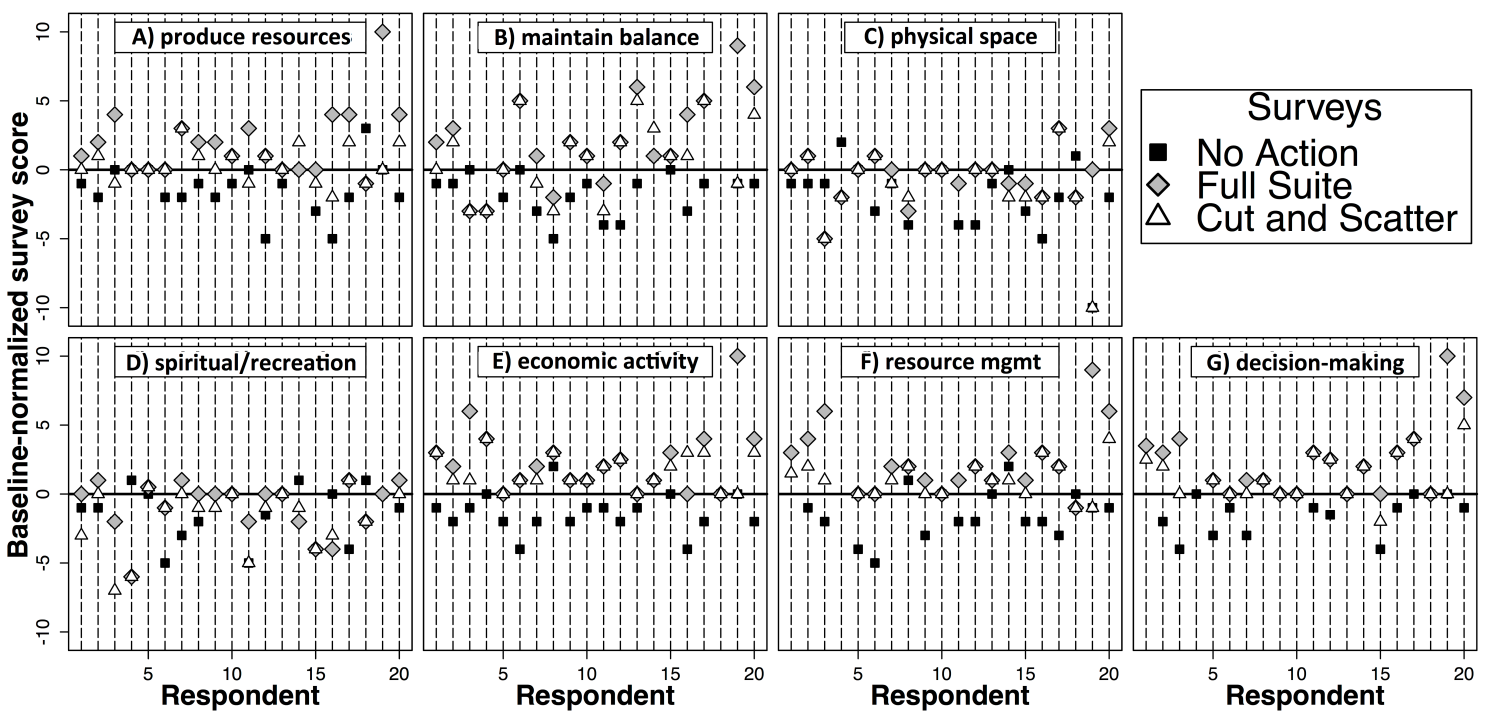

\section{Questionnaire results}

Altogether, the four questionnaires included 31 questions followed by scales for participants' responses. Our purposive sample of participants captured a diversity of perspectives in that the average observed range of responses was $81.6 \%$ of the total range possible (i.e., $100 \%$ ). To compare the perceived benefits or costs of juniper treatment, we normalized each participant's ratings by subtracting their "baseline" rating from the three alternative ratings (Fig. 3). On average, participants' ratings for future social-ecological conditions in the Owyhee region under the no-action alternative were 1.4 points lower than their baseline ratings. This suggests that most workshop participants perceived that if there were no action to remove juniper trees, future socialecological conditions in the Owyhee region would deteriorate. Participant ratings for the full-suite and cut-and-scatter alternatives were on average 1.4 points and 0.3 points higher than their baseline ratings, respectively. This suggests that many workshop participants perceived that implementation of either treatment alternative would improve future social-ecological conditions, but for some participants, the full-suite alternative would lead to a higher degree of improvement, bringing the Owyhee region closer to "as good as it can be." Some social conditions (i.e., economic, institutional, legal, and empowerment processes) were rated higher in a future with either the full-suite or cut-and-scatter alternative by almost all participants (Fig. 3E, F and G), whereas other ecological conditions (e.g., supporting service: open space, cultural service: opportunities for spiritual enrichment and recreation) were rated inconsistently across participants (Fig. 3C and D). On the acceptability of juniper removal within wilderness, participants' responses displayed substantial variation, indicating little consensus.

\section{Deliberative workshop results}

Workshop participants described 46 environmental changes and associated positive, negative, or neutral (i.e., no change) impacts that they anticipated to result from the $\mathrm{BOSH}$ project alternatives (Table 2; for complete findings see Appendix 1). Of the 18 changes to ecosystem services and social processes anticipated from the no-action alternative, 15 changes were perceived to lead to negative impacts, and 3 changes were perceived to lead to positive impacts to people and their sense of well-being. For example, if there is no action to remove juniper from the landscape, people anticipated experiencing negative impacts because of a reduction in watershed functionality, loss of biodiversity and habitat (particularly Sage-Grouse habitat), diminished spiritual experience, less opportunity in the local economy, and less opportunity for stakeholder collaboration. Positive impacts were expected to derive from the availability of areas without juniper removal for control group studies and from the improvement of overall enjoyment of the Owyhee region. The most striking split in opinion among participants related to perceived effects that no action would have on their overall enjoyment of the Owyhee region. Some participants enjoy the Owyhee region when they know it is managed and junipers are removed, particularly because of the belief that reduced juniper cover improves SageGrouse habitat. Other participants emphasized that junipers are native and that too much management is occurring. For those participants, the knowledge that nothing is being done to remove juniper is comforting and improves their overall enjoyment of the Owyhees.

We found participants' perceptions of potential social-ecological changes and subsequent effects from the full-suite and cut-andscatter alternatives to be mostly similar, although there were a few key differences. Workshop participants described five similar 
Table 2. Potential changes to social processes and ecosystem services with associated direction of impact as described by workshop participants, with example quotations. Sixteen examples are provided here to illustrate complexity and nuances in perceptions and descriptions collected during workshops. See Appendix 1 for all 46 potential changes and impacts.

\begin{tabular}{|c|c|c|c|}
\hline $\begin{array}{l}\text { Treatment option } \\
\text { Function within the } \\
\text { social-ecological } \\
\text { system }\end{array}$ & Potential change & Direction of impact & Example quotation \\
\hline \multicolumn{4}{|l|}{ No action } \\
\hline \multirow[t]{2}{*}{ Economic } & $\begin{array}{l}\text { Local economy: same } \\
\text { opportunity }\end{array}$ & No change & $\begin{array}{l}\text { "[The Bruneau-Owyhee Sage-Grouse Habitat proposal] does not deal with } \\
\text { economic issues driving the Owyhees." }\end{array}$ \\
\hline & $\begin{array}{l}\text { Tension on livestock } \\
\text { operators }\end{array}$ & Negative & $\begin{array}{l}\text { "The only thing for me that I perceive changing with a no action } \\
\text { alternative would be the future economic activity in the Owyhees, including } \\
\text { the way people make a living. With the potential listing of sage grouse, if } \\
\text { sage grouse are listed, that puts an added tension on especially livestock } \\
\text { operators, which is the major economic activity in the county." }\end{array}$ \\
\hline \multirow[t]{2}{*}{ Empowerment } & $\begin{array}{l}\text { Stakeholder collaboration: } \\
\text { less opportunity }\end{array}$ & Negative & $\begin{array}{l}\text { "There is a lot of agreement that some action is needed and if nothing } \\
\text { happens, folks may feel disenfranchised." }\end{array}$ \\
\hline & $\begin{array}{l}\text { Stakeholder collaboration: } \\
\text { same opportunity }\end{array}$ & No change & "Collaboration efforts exist but litigation will always be a challenge." \\
\hline \multirow[t]{2}{*}{ Provisioning } & Biodiversity: improved & Positive & "More trees - cooler streams, let nature take its course." \\
\hline & $\begin{array}{l}\text { Decline of historic plant } \\
\text { communities }\end{array}$ & Negative & $\begin{array}{l}\text { "The resources itself - historic plant communities, those types of things, } \\
\text { they're going to decline." }\end{array}$ \\
\hline \multicolumn{4}{|l|}{ Full suite } \\
\hline \multirow{3}{*}{$\begin{array}{l}\text { Institutional and } \\
\text { legal }\end{array}$} & Management: improved & Positive & "Management would be better through active work on the ground." \\
\hline & Management: worse & Negative & $\begin{array}{l}\text { "And we have enough problems as it is and when we do stuff like that it } \\
\text { makes us look even worse, especially this thing here... You know we have } \\
\text { our plan, it sounds great on paper, but when we don't get the money from } \\
\text { Congress or whatever to follow through, then we end up dealing with this } \\
\text { next thing that happens." }\end{array}$ \\
\hline & Management: no change & No change & $\begin{array}{l}\text { "The future of the efficiency - of the effectiveness of the management of } \\
\text { our supply of natural resources aren't going to change by us simply } \\
\text { removing the junipers... at some point in time once the juniper are gone } \\
\text { and we've created this habitat for sage grouse, let's go back to doing } \\
\text { something that's not going to bring the juniper back again." }\end{array}$ \\
\hline \multirow[t]{3}{*}{ Cultural } & Viewshed: improved & Positive & $\begin{array}{l}\text { "...for me personally, it would improve because I'd be able to go out to that } \\
\text { lek and not see that juniper stand there anymore. So for me personally, I'm } \\
\text { going to get to go out and be like: 'Wow, this is awesome. I feel like we } \\
\text { accomplished exactly what we set out to do. I can stand and look at those } \\
\text { birds and not see the juniper in the background."' }\end{array}$ \\
\hline & Viewshed: degraded & Negative & $\begin{array}{l}\text { "I know when I was at a Wildlife Refuge eight years ago, BLM [Bureau of } \\
\text { Land Management] came in around that area and cut down all the juniper } \\
\text { trees, and they just laid there for years. And eventually they went and they } \\
\text { started burning them up, but that was such a black eye for the BLM. The } \\
\text { locals around there, they're all like, 'Freaking waste.' All these trees lay and } \\
\text { it looked like crap." }\end{array}$ \\
\hline & Viewshed: no change & No change & $\begin{array}{l}\text { "...the average Joe is still going to drive into Mud Flat Road and see } \\
\text { exactly what they've always seen. They're not going to realize that on the } \\
\text { ground, there have been people that have been removing junipers out there } \\
\text { to improve sage grouse, or for whatever. Most people aren't going to notice } \\
\text { that." }\end{array}$ \\
\hline \multicolumn{4}{|l|}{ Cut and scatter } \\
\hline \multirow[t]{2}{*}{ Economic } & $\begin{array}{l}\text { Local economy: more } \\
\text { opportunity }\end{array}$ & Positive & "More jobs." \\
\hline & $\begin{array}{l}\text { Weakening of local } \\
\text { livelihoods }\end{array}$ & Negative & $\begin{array}{l}\text { "BLM regulations would probably still be a limiting factor in ranching } \\
\text { operations." }\end{array}$ \\
\hline \multirow[t]{3}{*}{ Supporting } & Wildlife habitat: improved & Positive & $\begin{array}{l}\text { "...at least we're getting trees cut and slashed, and that's great. That's a lot } \\
\text { better than doing nothing. A whole lot better, in my book, than doing } \\
\text { nothing." }\end{array}$ \\
\hline & & & $\begin{array}{l}\text { "We're talking about mostly Phase } 1 \text {. We're talking small trees - those can } \\
\text { get dropped pretty darn low to the ground, and there won't be a lot of fuel } \\
\text { buildup in those areas. So there are going to be a lot of positives, even if } \\
\text { that's what we were to do for the sage grouse." }\end{array}$ \\
\hline & $\begin{array}{l}\text { Increased cover for sage } \\
\text { grouse predators }\end{array}$ & Negative & $\begin{array}{l}\text { "...it's cut and scatter, so that'll take some of the cover away. It'll leave } \\
\text { more of the just the bole, and the branches will be scattered out. But there's } \\
\text { the potential it could create more cover." }\end{array}$ \\
\hline
\end{tabular}


environmental changes that they perceived could be caused by both alternatives, leading to negative effects: increased fire danger, degraded wildlife habitat, diminished viewsheds, worsened agency reputation, diminished management effectiveness, the latter two primarily for the BLM. Workshop participants described three similar environmental changes that they perceived could be caused by both alternatives leading to positive effects: improved watershed functionality, improved wildlife habitat, and more opportunity in the local economy. For the full suite, some participants anticipated additional positive effects, some of which included improved management, improved viewsheds, general enjoyment in the Owyhee region, and the maintenance of culture tied to cowboys and Sage-Grouse.

Contrary to those who anticipated both alternatives to cause certain social and ecological changes, other participants described that in a future under the full-suite alternative, there would be no change in some ranchers' ability to make a living, no change in management, and no change in viewshed or spiritual experience. The split in opinion about anticipated environmental changes was based on participants' varying perceptions of project scale and juniper removal tools. For example, some participants expressed concern that mastication would be applied across the entire project area, while others understood that mastication was proposed for roadsides only.

\section{Public participation GIS workshop results}

The PPGIS workshop comprised mapping activities based on two key questions: What areas across Owyhee County are important to you for social, economic, and/or ecological reasons? Within the BOSH project boundary, where do you not want juniper removed? Results from the first mapping activity (hereafter county values map) show that the overall distribution of perceived values (social, economic, and ecological combined) throughout the Owyhee region is highly associated with the two main watersheds (Owyhee and Bruneau-Jarbidge), wilderness areas (e.g., Owyhee River and near Juniper Mountain), and the town of Silver City (Fig. 4). Silver City is a historic mining town with a deep history and many cultural traditions. The Owyhee and Bruneau-Jarbidge watersheds are within significant portions of the Owyhee River and Bruneau-Jarbidge wilderness areas (Fig. 4A).

When we separated social, economic, and ecological values into three county value maps, the social (Fig. 4B) and ecological (Fig. 4D) values displayed similar patterns. However, we found more polygons per participant for ecological than social values. The polygons characterizing economic values were quite different than those for social and ecological values, and there were fewer polygons per participant for economic values (Fig. 4C). Economic values were mapped in a general sense (i.e., perhaps less precise) relative to the other values.

Justifications for the location of social, economic, and ecological polygons were diverse. Social polygons were generally drawn around areas that participants valued for the ranching or cowboy culture and tradition, and watershed- or wildlife-based recreation. Economic polygons were mapped to highlight the value of the ranching and farming industries, as well as tourism and the military. Ecological polygons were drawn across areas that participants found valuable for resource connectivity, wildlife and fisheries habitat, and biodiversity.
Fig. 4. Frequency of the polygons derived for all values combined (A), social values (B), economic values (C), and ecological values (D) in Owyhee County, Idaho, USA. Dotted lines indicate the proposed project boundary for the BruneauOwyhee Sage-Grouse Habitat project. Points 1 and 2 in (A) indicate the Owyhee and Bruneau-Jarbidge watersheds and associated wilderness areas.
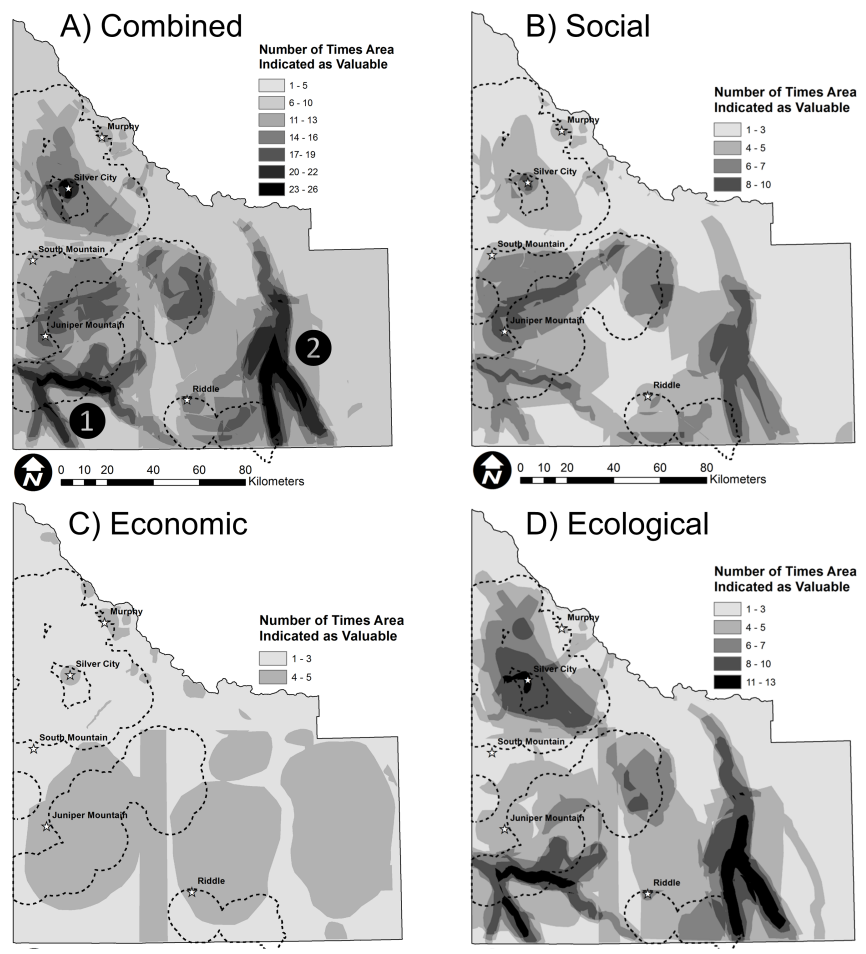

The second mapping activity (hereafter no-treatment map) served as a social setting filter, much like the ecological filter that narrows the scope of issues related to an intervention (Slootweg et al. 2001). The majority of participants indicated that the BOSH project will be positive and therefore did not draw any polygons; these participants support juniper removal over the entire project area. Some suggested no treatment around the city of Riddle because this area would be a lesser priority due to the perception that essentially no junipers are present. Others identified areas near Juniper Mountain because they are culturally valuable to the Shoshone-Paiute tribes. Finally, some participants indicated that they are against implementing the $\mathrm{BOSH}$ project entirely because they questioned the BLM's ability to complete the project goals without unintended consequences (e.g., spreading invasive species and leaving half-finished projects).

\section{DISCUSSION}

\section{Conceptual framework: ecosystem services and social change processes}

Our SEIA process advanced some of the major shortcomings of conventional EISs, including the lack of social-ecological integration. By merging previously developed conceptual frameworks that emphasize the connection and feedback between 
human systems and ecosystems, we were able to document socialecological dynamics and complexity in the potential impacts described by SEIA participants. The function evaluation flow diagram (Fig. 2; Slootweg et al. 2001) was a useful causal pathway heuristic for distinguishing environmental changes (social and ecological) from the positive or negative effects experienced by people. By using this causal pathway to articulate the interdependencies of ecosystem services, social processes, potential environmental changes, and potential impacts, workshop participants became, in effect, social-ecological systems thinkers. Recent research in environmental psychology suggests that a systems thinking mindset might be more malleable or amenable than political ideologies, for example, and that systems thinkers have a capacity to think more broadly about the range of potential environmental changes and consequences stemming from a decision or intervention (Lezak and Thibodeau 2016). The range of topics covered in our workshops demonstrated the importance of systems thinking using an integrated social-ecological framework for public lands where individual and community well-being depend on the environment. Most EISs to date are relatively devoid of social impacts and much less integrated with ecological and biophysical concepts in public land management contexts (Slootweg et al. 2001, Burdge 2002, Whitfield et al. 2011). Given that NEPA requires an interdisciplinary approach for the preparation of EISs (42 U.S.C. $\$ 4331$ ), the lack of social impacts puts current practice into question.

\section{Methodological approach: deliberative workshops and participatory mapping}

The deliberations over juniper removal alternatives and the discussions of perceived impacts were difficult to understand without incorporating spatial data. Incorporating the spatial dimension of participants' environmental values via participatory mapping allowed land managers to understand where interests and concerns were located within the Owyhee region. Values are the fundamental building blocks of perceptions about how one might be affected by a management intervention and environmental change, and visualizing this information on a map is helpful because public lands management is done in a spatial context (Lowery and Morse 2013). Mapping values and place meanings can be useful for identifying and prioritizing the most relevant issues to address with mitigation strategies. In our case, potential impacts associated with specific watersheds, wilderness, and historic towns were the top priorities for the BLM to address with mitigation. Mapping data can also aid project managers in decision making concerning where to stage juniper removal phases because the 708,200 ha project area will not be treated simultaneously.

Participatory mapping was also useful for clarifying misconceptions about the project, identifying unnecessary project boundaries, and deliberating areas to prioritize or disregard for juniper removal. We acknowledge that the composition of our total sample was weighted toward resource managers, possibly biasing the results. However, the data indicate that we captured a broad range of perspectives. For example, when anticipating changes to a viewshed as a result of juniper removal, participants described different perceptions of trail-level, ridge-line, horizon, and aerial views. Although an agency may frame a proposed project at one scale, we observed that participants framed potential impacts of the BOSH project at several scales, which fostered some ongoing confusion and is indicative of how even interested stakeholders may misgauge project goals and objectives. Precisely characterizing scale is a recognized issue in the field of ecology (e.g., Levin 1992), and our data suggest that the same level of precision is needed when discussing socialecological effects associated with land management actions. These observations are consistent with previous research on qualitative approaches to PPGIS that reported benefits such as positive synergy among participants and clarified perceptions of project scale (Lowery and Morse 2013).

In addition to the PPGIS workshops, the deliberative workshops addressed the need to improve the role of affected people in impact assessment processes. In our case, the participatory impact assessment led to a change in drafted juniper removal alternatives. Prior to the SEIA, both the full-suite and cut-and-scatter alternatives included federally designated wilderness. During the SEIA, concerns about "guarding or gardening" wilderness were voiced, and $\mathrm{BOSH}$ project managers subsequently drafted an alternative that excludes wilderness areas from the proposed treatment areas. The benefits of these workshops are consistent with previous research that observed improved opportunities for community members to share their perceptions about proposed actions and potential futures in a deliberative setting (Becker et al. 2003, Harris et al. 2012). Typical scoping processes, during which people write or call the planning agency with their concerns, normally do not identify such nuances. A deliberative approach to SEIA can enhance scoping in a NEPA process by providing an opportunity for people to elaborate their concerns or support for a project, improve their understanding of a project, and discuss and negotiate potential outcomes with project leaders and other stakeholders.

Collectively, our results provide BLM managers with a range of perceptions useful for developing a more holistic and comprehensive EIS, and land management options that will likely be more agreeable to a broad range of stakeholders, thereby increasing the potential for project buy-in and standing in court. Altogether, managers and scholars will find SEIA useful for expanding traditional scoping methods, improving opportunities for stakeholder engagement, capturing diverse perspectives on changing social-ecological conditions, prioritizing areas for project implementation, and achieving a more interdisciplinary, participatory, and lawful NEPA process and product.

The strength of this approach is the application of a socialecological conceptual framework that includes social processes as functions from which humans can derive benefits (or costs) alongside and interdependent with ecosystem services. This integrated framework is applied within a deliberative setting that includes questionnaires, dialogue, and a qualitative approach to PPGIS. By building on a theoretical convergence of systems thinking, complexity theory, and social constructivism, and by merging the integrated conceptual framework and mixedmethodological approach, the SEIA process enabled triangulation of multiscale social-ecological impacts associated with the proposed BOSH project.

\section{CONCLUSION}

Social-ecological systems are complex, as are the perceptions of humans who have a vested interest in shared public lands. This 
SEIA supports holistic understanding and framing of connections between humans and ecosystems in a contextual and spatially explicit way, and enables land managers and affected people to codevelop more comprehensive management plans and conservation goals. The SEIA is not designed to replace a traditional ecological impact assessment, for which ecological and biophysical monitoring data are analyzed, nor do we intend for SEIA to replace traditional economic impact assessments. Rather, SEIA is meant to complement other assessments by defining the connections between people and their environment and highlighting how those connections might be weakened or strengthened by land management decisions. We support the notion that impact assessments are context dependent (Vanclay 2002), and we recommend a modification of social-ecological concepts in the framework or the tools for data collection depending on environmental characteristics, politics, and power dynamics specific to the project area (Ross and McGee 2006). Continued applications of integrated frameworks such as SEIA within public lands management would better satisfy NEPA requirements and assist the design of more complete mitigation strategies. The advancement of conservation efforts relies in part on our ability to assess comprehensively the social and ecological consequences of human interventions on public lands (e.g., Brashares et al. 2014). The SEIA we developed and described here contributes to this broader conservation goal.

\section{Responses to this article can be read online at:}

http://www.ecologyandsociety.org/issues/responses. $\mathrm{php} / 8569$

\section{Acknowledgments:}

We are sincerely grateful to M. McGee, L. Okeson, J. Suhr Pierce, A. Talsma, and D. Miller for logistical support and willingness to support new ideas. We thank the National Science Foundation IGERT program (Award 0903479), Bureau of Land Management (Award L14AC00060), and Idaho Governor's Office of Species Conservation (Award BOSEIA14) for financial and logistical support. Finally, we thank $M$. Brunson and S. Donovan for providing comments that greatly improved this manuscript.

\section{LITERATURE CITED}

Bartlett, E. T., L. A. Torell, N. R. Rimbey, L. W. Van Tassell, and D. W. McCollum. 2002. Valuing grazing use on public land. Journal of Range Management 55(5):426-438. http://dx.doi. org/10.2307/4003220

Baruch-Mordo, S., J. S. Evans, J. P. Severson, D. E. Naugle, J. D. Maestas, J. M. Kiesecker, M. J. Falkowski, C. A. Hagen, and K. P. Reese. 2013. Saving sage-grouse from the trees: a proactive solution to reducing a key threat to a candidate species. Biological Conservation 167:233-241. http://dx.doi.org/10.1016/j.biocon.2013.08.017

Becker, D. R., C. C. Harris, W. J. McLaughlin, and E. A. Nielsen. 2003. A participatory approach to social impact assessment: the interactive community forum. Environmental Impact Assessment Review 23(3):367-382. http://dx.doi.org/10.1016/S0195-9255(02) 00098-7
Becker, H. A. 1997. Social impact assessment: method and experience in Europe, North America and the developing world. UCL Press, London, UK.

Brashares, J. S., B. Abrahms, K. J. Fiorella, C. D. Golden, C. E. Hojnowski, R. A. Marsh, D. J. McCauley, T. A. Nuñez, K. Seto, and L. Withey. 2014. Wildlife decline and social conflict. Science 345:376-378. http://dx.doi.org/10.1126/science.1256734

Brown, G. 2004. Mapping spatial attributes in survey research for natural resource management: methods and applications. Society and Natural Resources 18(1):17-39. http://dx.doi. org/10.1080/08941920590881853

Brown, G. G., and S. Donovan. 2013. Escaping the national forest planning quagmire: using public participation GIS to assess acceptable national forest use. Journal of Forestry 111(2):115-125. http://dx.doi.org/10.5849/jof.12-087

Brown, G. G., and D. V. Pullar. 2012. An evaluation of the use of points versus polygons in public participation geographic information systems using quasi-experimental design and Monte Carlo simulation. International Journal of Geographical Information Science 26(2):231-246. http://dx.doi. org/10.1080/13658816.2011.585139

Brown, G., and D. Weber. 2011. Public participation GIS: a new method for national park planning. Landscape and Urban Planning 102(1):1-15. http://dx.doi.org/10.1016/j.landurbplan.2011.03.003

Burdge, R. J. 2002. Why is social impact assessment the orphan of the assessment process? Impact Assessment and Project Appraisal 20(1):3-9. http://dx.doi.org/10.3152/147154602781766799

Checkland, P. 1981. Systems thinking, systems practice. Wiley, Chichester, UK.

Cline, N. L., B. A. Roundy, F. B. Pierson, P. Kormos, and C. J. Williams. 2010. Hydrologic response to mechanical shredding in a juniper woodland. Rangeland Ecology and Management 63 (4):467-477. http://dx.doi.org/10.2111/REM-D-09-00196.1

Council on Environmental Quality. 2007. A citizen's guide to the NEPA: having your voice heard. Council on Environmental Quality, Washington, D.C., USA. [online] URL: http://ceq.doe. gov/publications/citizens guide to nepa.html

Cundill, G., G. S. Cumming, D. Biggs, and C. Fabricius. 2012. Soft systems thinking and social learning for adaptive management. Conservation Biology 26(1):13-20. http://dx.doi. org/10.1111/j.1523-1739.2011.01755.x

Cundill, G., and R. Rodela. 2012. A review of assertions about the processes and outcomes of social learning in natural resource management. Journal of Environmental Management 113:7-14. http://dx.doi.org/10.1016/j.jenvman.2012.08.021

Daniels, S. E., and G. B. Walker. 1996. Collaborative learning: improving public deliberation in ecosystem-based management. Environmental Impact Assessment Review 16(2):71-102. http://dx. doi.org/10.1016/0195-9255(96)00003-0

de Groot, R. S., R. Alkemade, L. Braat, L. Hein, and L. Willemen. 2010. Challenges in integrating the concept of ecosystem services and values in landscape planning, management and decision making. Ecological Complexity 7(3):260-272. http://dx.doi. org/10.1016/j.ecocom.2009.10.006 
de Groot, R. S., M. A. Wilson, and R. M. J. Boumans. 2002. A typology for the classification, description and valuation of ecosystem functions, goods and services. Ecological Economics 41(3):393-408. http://dx.doi.org/10.1016/S0921-8009(02)00089-7

ESRI. 2012. ArcGIS desktop: release 10.1. Environmental Systems Research Institute, Redlands, California, USA.

Esteves, A. M., D. Franks, and F. Vanclay. 2012. Social impact assessment: the state of the art. Impact Assessment and Project Appraisal 30(1):34-42. http://dx.doi.org/10.1080/14615517.2012.660356

Folke, C. 2006. Resilience: the emergence of a perspective for social-ecological systems analyses. Global Environmental Change 16(3):253-267. http://dx.doi.org/10.1016/j.gloenvcha.2006.04.002

Franks, D. M., D. Brereton, and C. J. Moran. 2011. Cumulative social impacts. Pages 202-220 in F. Vanclay and A. M. Esteves, editors. New directions in social impact assessment: conceptual and methodological advances. Edward Elgar, Cheltenham, UK. http:// dx.doi.org/10.4337/9781781001196.00024

Gunderson, K., and A. Watson. 2007. Understanding place meanings on the Bitterroot National Forest, Montana. Society and Natural Resources 20(8):705-721. http://dx.doi.

org/10.1080/08941920701420154

Harris, C. C., E. A. Nielsen, D. R. Becker, D. J. Blahna, and W. J. McLaughlin. 2012. Results of community deliberation about social impacts of ecological restoration: comparing public input of self-selected versus actively engaged community members. Environmental Management 50(2):191-203. http://dx.doi.org/10.1007/ s00267-012-9871-0

Holling, C. S. 2001. Understanding the complexity of economic, ecological, and social systems. Ecosystems 4(5):390-405. http:// dx.doi.org/10.1007/s10021-001-0101-5

Honeycutt, D. 2013. Count overlapping polygons. Environmental Systems Research Institute, Redlands, California, USA. [online] URL http://www.arcgis.com/home/item.html?id=1dd4a6832b3d40b494dbf8521cc5134c

Huffman, D. W., P. Z. Fulé, J. E. Crouse, and K. M. Pearson. 2009. A comparison of fire hazard mitigation alternatives in pinyon-juniper woodlands of Arizona. Forest Ecology and Management 257(2):628-635. http://dx.doi.org/10.1016/j. foreco.2008.09.041

Knick, S. T., D. S. Dobkin, J. T. Rotenberry, M. A. Schroeder, W. M. Vander Haegen, and C. van Riper III. 2003. Teetering on the edge or too late? Conservation and research issues for avifauna of sagebrush habitats. Condor 105(4):611-634. http://dx.doi. org/10.1650/7329

Levin, S. A. 1992. The problem of pattern and scale in ecology: the Robert H. MacArthur Award lecture. Ecology 73 (6):1943-1967. http://dx.doi.org/10.2307/1941447

Lezak, S. B., and P. H. Thibodeau. 2016. Systems thinking and environmental concern. Journal of Environmental Psychology 46:143-153. http://dx.doi.org/10.1016/j.jenvp.2016.04.005

Lincoln, Y. S., and E. G. Guba. 1985. Naturalistic inquiry. Sage, Newbury Park, California, USA.

Lincoln, Y. S., and E. G. Guba. 2013. The constructivist credo. Left Coast Press, Walnut Creek, California, USA.
Lockie, S. 2001. SIA in review: setting the agenda for impact assessment in the 21st century. Impact Assessment and Project Appraisal 19(4):277-287. http://dx.doi.org/10.3152/147154601781766952

Lowery, D. R., and W. C. Morse. 2013. A qualitative method for collecting spatial data on important places for recreation, livelihoods, and ecological meanings: integrating focus groups with public participation geographic information systems. Society and Natural Resources 26(12):1422-1437. http://dx.doi. org/10.1080/08941920.2013.819954

Mackun, P. J., and S. Wilson. 2011. Population distribution and change: 2000 to 2010. U.S. Department of Commerce, Economics and Statistics Administration, U.S. Census Bureau, Washington, D.C., USA. [online] URL: https://www.census.gov/prod/cen2010/ briefs/c2010br-01.pdf

Parkins, J. R., and R. E. Mitchell. 2005. Public participation as public debate: a deliberative turn in natural resource management. Society and Natural Resources 18(6):529-540. http://dx.doi.org/10.1080/08941920590947977

Patton, M. Q. 2015. Qualitative research and evaluation methods: integrating theory and practice. Fourth edition. Sage, Thousand Oaks, California, USA.

QSR International. 2012. NVivo qualitative data analysis software. Version 10. QSR International, Burlington, Massachusetts, USA.

R Core Team. 2014. R: a language and environment for statistical computing. R Foundation for Statistical Computing, Vienna, Austria. [online] URL: https://www.r-project.org/

Romme, W. H., C. D. Allen, J. D. Bailey, W. L. Baker, B. T. Bestelmeyer, P. M. Brown, K. S. Eisenhart, M. L. Floyd, D. W. Huffman, B. F. Jacobs, R. F. Miller, E. H. Muldavin, T. W. Swetnam, R. J. Tausch, and P. J. Weisberg. 2009. Historical and modern disturbance regimes, stand structures, and landscape dynamics in piñon-juniper vegetation of the western United States. Rangeland Ecology and Management 62(3):203-222. http:// dx.doi.org/10.2111/08-188R1.1

Ross, H., and T. K. McGee. 2006. Conceptual frameworks for SIA revisited: a cumulative effects study on lead contamination and economic change. Impact Assessment and Project Appraisal 24(2):139-149. http://dx.doi.org/10.3152/147154606781765273

Slootweg, R., F. Vanclay, and M. van Schooten. 2001. Function evaluation as a framework for the integration of social and environmental impact assessment. Impact Assessment and Project Appraisal 19(1):19-28. http://dx.doi.org/10.3152/147154601781767186

Talen, E. 2000. Bottom-up GIS: a new tool for individual and group expression in participatory planning. Journal of the American Planning Association 66(3):279-294. http://dx.doi. org/10.1080/01944360008976107

Tausch, R. J., N. E. West, and A. A. Nabi. 1981. Tree age and dominance patterns in Great Basin pinyon-juniper woodlands. Journal of Range Management 34(4):259-264. http://dx.doi. org/10.2307/3897846

U.S. Department of the Interior. 2015. Historic conservation campaign protects greater sage-grouse. Press release. U.S. Department of the Interior, Washington, D.C., USA. [online] 
URL: https://www.doi.gov/pressreleases/historic-conservationcampaign-protects-greater-sage-grouse

U.S. Fish and Wildlife Service (USFWS). 2010. Endangered and threatened wildlife and plants; 12 -month findings for petitions to list the greater sage-grouse (Centrocercus urophasianus) as threatened or endangered. Federal Register 75:13910-14014. [online] URL: https://federalregister.gov/a/2010-5132

Vanclay, F. 2002. Conceptualising social impacts. Environmental Impact Assessment Review 22(3):183-211. http://dx.doi. org/10.1016/S0195-9255(01)00105-6

Vanclay, F., and A. M. Esteves, editors. 2011. New directions in social impact assessment: conceptual and methodological advances. Edward Elgar, Cheltenham, UK. http://dx.doi.org/10.4337/978$\underline{1781001196}$

Whitfield, S., H. J. Geist, and A. A. R. Ioris. 2011. Deliberative assessment in complex socioecological systems: recommendations for environmental assessment in drylands. Environmental Monitoring and Assessment 183(1):465-483. http://dx.doi. org/10.1007/s10661-011-1933-X

Whitfield, S., and M. S. Reed. 2012. Participatory environmental assessment in drylands: introducing a new approach. Journal of Arid Environments 77:1-10. http://dx.doi.org/10.1016/j.jaridenv.2011.09.015 
Appendix 1. Potential changes to social processes and ecosystem services with associated direction of impact as described by workshop participants with example quotes.

Table 1. Workshop participants' responses to the no action alternative.

\begin{tabular}{|c|c|c|c|}
\hline $\begin{array}{l}\text { Social-ecological } \\
\text { system characteristic }\end{array}$ & Potential Change & Direction of Impact & Example Quote \\
\hline Economic Processes & $\begin{array}{l}\text { Local economy - same } \\
\text { opportunity }\end{array}$ & No Change & $\begin{array}{l}\text { "[The BOSH proposal] does not deal with economic issues } \\
\text { driving the Owyhees." }\end{array}$ \\
\hline $\begin{array}{l}\text { Institutional and legal } \\
\text { processes }\end{array}$ & $\begin{array}{l}\text { Disheartening to land } \\
\text { managers }\end{array}$ & Negative & $\begin{array}{l}\text { "So if you're not going to do anything, it's really } \\
\text { disheartening to everybody that worked all those years, and } \\
\text { biologists, and it's in every plan, the Owyhee [Initiative], the } \\
\text { Governor's task force, the state plan. It would be a big } \\
\text { discouragement to everybody." }\end{array}$ \\
\hline $\begin{array}{l}\text { Institutional and legal } \\
\text { processes }\end{array}$ & $\begin{array}{l}\text { Endangered listing - } \\
\text { Greater sage grouse }\end{array}$ & Negative & $\begin{array}{l}\text { "But I think there's, what I like to say is that, the impact to the } \\
\text { people I think may not be as much related to, okay we're } \\
\text { going to have more juniper out there, but it may simply be } \\
\text { how a (sage grouse) listing decision affects the community out } \\
\text { there." }\end{array}$ \\
\hline
\end{tabular}


Empowerment processes

Stakeholder

collaboration - less

opportunity

Empowerment processes

Provisioning

Provisioning

Processing

Processing

Supporting

Supporting

Cultural
Stakeholder

collaboration - same

opportunity

Impact to ecosystem

Decline of historic plant communities

Ability to balance or restore landscape / ecological processes more difficult

Reduction of watershed functionality

Loss of biodiversity $\&$ habitat

Loss of sage grouse habitat

Availability of areas without treatment for study
Negative

Negative

No Change

Positive

Negative

Negative

Negative

Negative

Positive
"There is a lot of agreement that some action is needed and if nothing happens, folks may feel disenfranchised."

"Collaboration efforts exist but litigation will always be a challenge."

"More trees - cooler streams, let nature take its course."

"The resources itself - historic plant communities, those types of things, they're going to decline."

"...the ecological site condition will continue to deviate from the historical condition affecting watershed, range \& grazing, wildlife."

"When juniper encroaches on springs and streams, it reduces their functionality. There's at least plenty of anecdotal evidence of juniper leading to springs drying up, reducing water output."

"The area will lose diversity as juniper monocultures develop."

"Are we able to actually effectively manage the habitat for sage grouse to offset these big losses we're going to have?"

"And as far as not taking trees out, I think that would be great. I realize that it's actually maybe it gives you an area that you can actually do some studies to figure out what's going on because you haven't messed with this, you can have this area 


\begin{tabular}{|c|c|c|c|}
\hline Cultural & $\begin{array}{l}\text { General enjoyment of } \\
\text { the Owyhees - improved }\end{array}$ & Positive & $\begin{array}{l}\text { "Because there won't be this specific manipulation in } \\
\text { wilderness." }\end{array}$ \\
\hline Cultural & $\begin{array}{l}\text { General enjoyment of } \\
\text { the Owyhees - no } \\
\text { change }\end{array}$ & No Change & "Action or no action will have minor effect if any" \\
\hline Cultural & Loss of open space & Negative & $\begin{array}{l}\text { "There would be loss of open space...you would lose the } \\
\text { sagebrush views." }\end{array}$ \\
\hline Cultural & Limits on recreation & Negative & $\begin{array}{l}\text { "[Big impact to Owyhee County] on recreation... everything } \\
\text { from motorized, which a lot of people use down there...no } \\
\text { hunting season for the sage grouse." }\end{array}$ \\
\hline Cultural & Less aesthetic enjoyment & Negative & $\begin{array}{l}\text { "Aesthetic enjoyment would decrease for me [due to] loss of } \\
\text { sagebrush/sage-steppe." }\end{array}$ \\
\hline Cultural & Hunting - diminished & Negative & $\begin{array}{l}\text { "Areas will have reduced value for human activity as juniper } \\
\text { continues to expand = decreased recreation, hunting, } \\
\text { decreased quality areas for wildlife." }\end{array}$ \\
\hline Cultural & $\begin{array}{l}\text { Spiritual experience - } \\
\text { diminished }\end{array}$ & Negative & $\begin{array}{l}\text { "I think the [spiritual] opportunities available now are a result } \\
\text { of the landscape available if it changes these may cease to } \\
\text { exist." }\end{array}$ \\
\hline Cultural & $\begin{array}{l}\text { Spiritual experience }- \text { no } \\
\text { change }\end{array}$ & No Change & $\begin{array}{l}\text { "You know for me with the exception of the spirituality } \\
\text { portion because I think you can find the spirituality of it } \\
\text { whether they're sagebrush, sage grouse, junipers - there's a } \\
\text { beauty in whatever aspect of it." }\end{array}$ \\
\hline
\end{tabular}

that hasn't had a treatment on it, maybe somebody can get in there and figure out what was really going on."

"Because there won't be this specific manipulation in 
Table 2. Workshop participants' responses to the full suite alternative.

\begin{tabular}{|c|c|c|c|}
\hline $\begin{array}{c}\text { Social-ecological } \\
\text { system characteristic }\end{array}$ & Potential Change & Direction of Impact & Quote \\
\hline Economic Processes & $\begin{array}{l}\text { Ability to make a } \\
\text { living - improved }\end{array}$ & Positive & "More jobs for loggers." \\
\hline $\begin{array}{l}\text { Institutional and legal } \\
\text { processes }\end{array}$ & $\begin{array}{l}\text { Management - no } \\
\text { change }\end{array}$ & No Change & $\begin{array}{l}\text { "The future of the efficiency - of the effectiveness of the } \\
\text { management of our supply of natural resources aren't going } \\
\text { to change by us simply removing the junipers... at some } \\
\text { point in time once the juniper are gone and we've created }\end{array}$ \\
\hline
\end{tabular}


Institutional and legal processes

\section{Empowerment processes}

Provisioning

Processing

Processing

Supporting
Worsened agency

reputation

Negative

Stakeholder

collaboration - more

opportunity

Range and grazing improved

Positive

Positive

this habitat for sage grouse, let's go back to doing something that's not going to bring the juniper back again."

"I work for the BLM, that's my job. I'm not here representing the BLM, but I actually work for the BLM. And we have enough problems as it is and when we do stuff like that it makes us look even worse."

"People will see the fruits of the labor and will want to keep collaborating if their contributions are influencing positive change."

"I think if it's implemented, we're trying to get this juniper removed, that will improve range conditions, and it will improve grazing. It will improve ranching operations. And I think if we're able to use equipment and masticators and stuff, then we can have a bigger impact on juniper encroachment and reduce it at a bigger scale than what we're limited to hand crews and stuff."

Increased watershed

Positive

"Increased watershed and overall ecological health." functionality

Increased fire danger

Negative

"But when it gets down to actually implementing it I'll bet you we end up with a bunch of dead trees out there that look like crap that maybe you're going to end up catching or actually causing the fire because now you've got all this dead wood that you've left laying around."

"Taking action in areas where we will see the most positive + cost effective benefits $=$ more habitat for wildlife, lands for hunting/recreation; hopeful treatment/action to improve sage-grouse habitat - keeping it from being listed, and more 


\begin{tabular}{|c|c|c|c|}
\hline Supporting & $\begin{array}{l}\text { Wildlife habitat - } \\
\text { improved }\end{array}$ & Positive & $\begin{array}{l}\text { "I think it's agreed that sage grouse is kind of a keystone } \\
\text { species that if the habitat is improved for them, deer and elk } \\
\text { and a vast majority of other species kind of are also } \\
\text { positively benefitted," }\end{array}$ \\
\hline \multirow[t]{2}{*}{ Supporting } & $\begin{array}{l}\text { Wildlife habitat - } \\
\text { degraded }\end{array}$ & Negative & $\begin{array}{l}\text { "A lot of blue birds, chickadees other birds that are cavity } \\
\text { nesters, they need junipers to nest in. So they would } \\
\text { definitely be affected..." }\end{array}$ \\
\hline & & & $\begin{array}{l}\text { "One of the issues, if you do have a lot of mechanical } \\
\text { treatment, you do have to worry about noxious weeds. And } \\
\text { hopefully the outcome is good. And you do have to worry } \\
\text { about soil disturbance. And also disruption of wildlife and if } \\
\text { it's a sensitive nesting time or things like that." }\end{array}$ \\
\hline Supporting & $\begin{array}{l}\text { Sage grouse habitat - } \\
\text { maintained/improved }\end{array}$ & Positive & $\begin{array}{l}\text { "I think it's agreed that sage grouse is kind of a keystone } \\
\text { species that if the habitat is improved for them, deer and elk } \\
\text { and a vast majority of other species kind of are also } \\
\text { positively benefitted." }\end{array}$ \\
\hline Cultural & $\begin{array}{l}\text { General enjoyment of } \\
\text { the Owyhees - } \\
\text { improved }\end{array}$ & Positive & $\begin{array}{l}\text { "Increased diversity of animals and habitat will create better } \\
\text { experiences for more people with diverse interests," }\end{array}$ \\
\hline Cultural & Solitude - no change & No Change & $\begin{array}{l}\text { "I'm trying to keep in mind the scale of what we're talking } \\
\text { about as far as Phase I, really early Phase II juniper. Yes, } \\
\text { it'll be a success for us if we're actually able to do } \\
\text { something out there, but as far as any other changes that are } \\
\text { occurring, I guess personally I don't see much in that } \\
\text { change... as far as... people's feeling of solitude." }\end{array}$ \\
\hline Cultural & Hunting - improved & Positive & "Taking action in areas where we will see the most positive \\
\hline
\end{tabular}


Cultural

Cultural

no change

Cultural

Viewshed - improved

Cultural

Viewshed - degraded

Negative

Cultural
Recreation -

Recreation - disrupted

Negative

No change
Positive

+ cost effective benefits $=$ more habitat for wildlife, lands for hunting/recreation; hopeful treatment/action to improve sage-grouse habitat - keeping it from being listed, and more diversity."

"The treatment activities will be disruptive to recreationists for a period of time."

"For instance, well it hasn't changed the future physical space that's suitable for human activities. I guess it depends on what human activity you want. If the junipers are there, there's a human activity that can still be used whether it's watching birds or it's hunting whatever the case. You remove those junipers, to some degree, those human activities are still available - may not be the exact same."

“...for me personally, it would improve because I'd be able to go out to that lek and not see that juniper stand there anymore. So for me personally, I'm going to get to go out and be like, "Wow, this is awesome." I feel like we accomplished exactly what we set out to do. I can stand and look at those birds and not see the juniper in the background."

"I know when I was at a Wildlife Refuge eight years ago, BLM came in around that area and cut down all the juniper trees, and they just laid there for years. And eventually they went and they started burning them up, but that was such a black eye for the BLM. The locals around there, they're all like, "Freaking waste." All these trees lay and it looked like crap."

“...the average Joe is still going to drive into Mud Flat 
Cultural

Cultural

Cultural
Spiritual experience improved

Spiritual experience no change

Culture tied to cowboy

\& sage grouse -

maintained
Road and see exactly what they've always seen. They're not going to realize that on the ground, there have been people that have been removing junipers out there to improve sage grouse, or for whatever. Most people aren't going to notice that."

Positive

"But for the scope of this project, it will improve my personal spirituality or whatever, if you will, because I can actually now visually see this - no more trees within this area, this lek, these encroaching junipers are gone,"

No Change

"Again I go back to the fact that I can find beauty in a butterfly on a juniper as easily as I can find beauty in a butterfly on a sagebrush. So that aspect of my spiritual portion of it doesn't change by the fact that we do or do nothing to it."

Positive

"It's not just the cowboy aspect. I love sage grouse, you know. And I think having all the tools available, having all the resources available is from the get-go probably the best option." 
Table 3. Workshop participants' responses to the cut and scatter alternative.

\begin{tabular}{|c|c|c|c|}
\hline $\begin{array}{c}\text { Social-ecological } \\
\text { system characteristic }\end{array}$ & Potential Change & Direction of Impact & Quote \\
\hline Economic processes & $\begin{array}{l}\text { Weakening of local } \\
\text { livelihoods }\end{array}$ & Negative & $\begin{array}{l}\text { "BLM regulations would probably still be a limiting factor } \\
\text { in ranching operations." }\end{array}$ \\
\hline $\begin{array}{l}\text { Institutional and legal } \\
\text { processes }\end{array}$ & $\begin{array}{l}\text { Management } \\
\text { effectiveness - } \\
\text { diminished }\end{array}$ & Negative & $\begin{array}{l}\text { "The efficiency of management would be reduced since } \\
\text { mastication and jackpot burns are useful tools for juniper } \\
\text { encroachment," and "So if those tools aren't available, you } \\
\text { may not treat the acres you'd like or as effective as you'd } \\
\text { like." }\end{array}$ \\
\hline Provisioning & $\begin{array}{l}\text { Ecosystem health and } \\
\text { characteristics - } \\
\text { improved }\end{array}$ & Positive & $\begin{array}{l}\text { "In 5-15 years there would be some improvement in soil } \\
\text { and water resources. Grasses would improve also." }\end{array}$ \\
\hline Provisioning & $\begin{array}{l}\text { Increased water } \\
\text { availability }\end{array}$ & Positive & $\begin{array}{l}\text { "...getting that functioning ecosystem we can pretty much } \\
\text { all agree on... without water, nothing functions... water is } \\
\text { the sustaining thing of life, period." }\end{array}$ \\
\hline Processing & $\begin{array}{l}\text { Watershed } \\
\text { functionality - } \\
\text { improved }\end{array}$ & Positive & $\begin{array}{l}\text { "slowed on fields and hills" and when "you get snow } \\
\text { blowing up against the back end or on the north face, then } \\
\text { you've got extra protections." }\end{array}$ \\
\hline
\end{tabular}


Supporting

Supporting

Supporting

Cultural

Viewshed - degraded

Cultural

$$
\begin{aligned}
& \text { Wildlife habitat - } \\
& \text { improved }
\end{aligned}
$$
degraded

Increased cover for sage grouse predators

Positive

.

